\title{
Anticancer Activity of Micromeria fruticosa and Teucrium polium Growing in Lebanon
}

\author{
Mohammad Al-Hamwi ${ }^{1, *}$, Maha Aboul-Ela ${ }^{1}$, Abdalla El-Lakany ${ }^{1}$, Salam Nasreddine ${ }^{2}$
}

\section{Mohammad Al-Hamwi ${ }^{1, *}$, Maha Aboul-Ela', Abdalla El-Lakany', Salam Nasreddine ${ }^{2}$}

'Department of Pharmaceutical Sciences, Beirut Arab University, Beirut, Lebanon, P.O. 11 5020, Beirut, LEBANON.

${ }^{2}$ Group A nti-Cancer Therapeutic Approaches (ACTAC), Laboratory Rammal Rammal, Biology Department, Faculty of Sciences, Lebanese University, LEBANON.

\section{Correspondence}

\section{Mohammad Al-Hamwi}

Department of Pharmaceutical Sciences, Beirut Arab University, Beirut, Lebanon, P.O. 11 5020, Beirut, LEBANON.

Phone no: +961 3 319211;

E-mail: abumuath_09@hotmail.com

\section{History \\ - Submission Date: 21-09-2020; \\ - Review completed: 09-11-2020; \\ - Accepted Date: 04-12-2020.}

DOI : 10.5530/pj.2021.13.15

Article Available online http://www.phcogj.com/v13/i1

\section{Copyright}

(C) 2021 Phcogj.Com. This is an openaccess article distributed under the terms of the Creative Commons Attribution 4.0 International license.

\section{ABSTRACT}

The anticancer activities of two Lebanese plant extract Micromeria fruticose (A) and Teucrium polium (B) and their fractions were tested against MCF7 and A549 cancer cell lines using MTT assay. Separation was carried out through column chromatography and TLC analysis. Results showed that both plants possess a promising and dose dependent inhibitory activity with IC50of extract A 28.52 and $26.47 \mu \mathrm{g} / \mathrm{ml}$ on MCF7 and A549 cells respectively, and that of extract B was 41 and $27.9 \mu \mathrm{g} / \mathrm{ml}$ on MCF7 and A549 cell lines, respectively. More interestingly, combination treatment with either extracts A or B and cisplatin, significantly boosted the cytotoxic effect of cisplatin against the two cancer cell lines. Further studies are recommended to determine the active components in both plants responsible for these activities and explore their interactions at molecular level.

\section{INTRODUCTION}

Medicinal plants have been widely utilized for tumor and cancer prevention ${ }^{1,2}$. Over $60 \%$ of today's anticancer chemotherapeutic drugs originate from natural sources as plants ${ }^{3,4}$. Family Lamiaceae (or Labiatae), is a flowering plant that has roughly 236 genera and more than7000 species ${ }^{5}$, of which the genus Micromeria and Teucrium. Micromeria ${\text { fructicos } a^{6} \text { and Teucrium polium }}^{7}$ (Lamiaceae) are perennial herbs or shrubs that dwells in rocky and dry-open territories in the Mediterranean areas like Turkey, Syria, and Lebanon ${ }^{8,9}$.

Plants of Family Lamiaceae, including that of genus Micomeria and Teucrium, are well known for their therapeutic potential and have been widely used to treat many ailments as migraines, gastrointestinal disorders, upper respiratory tract infections, and some cardiovascular diseases ${ }^{10}$. Micromeria plants was reported to possess antimicrobial activities beneficial for the treatment of common cold, wounds, and skin infections ${ }^{11-13}$. Other studies suggested its protective effect against hepatotoxicity and pain management ${ }^{14-16}$. On the other hand, Teucrium plant were utilized to treat abscesses, conjunctivitis, gout, inflammation, parasitic infections, and diabetes ${ }^{17}$. Both plants (Micromeria and Teucrium) are considered as important source of phenolic, terpenoidal, and flavonoidal compounds ${ }^{18}$. This abundance of polyphenolic components stands behind the antioxidant quality and the wide range of reported pharmacological activities of both genus ${ }^{19}$.

Numerous studies have elaborated the importance of phenolic compounds and the distinct anticancer effects of Teucrium plants. Extracts from $T$. polium were capable of diminishing cell invasion and metastasis of human prostate cancer cells ${ }^{20}$, promoting cell apoptosis of human lung carcinoma cells $^{21}$, and inhibiting breast adenocarcinoma cancerous cell growth ${ }^{22}$. Moreover, it was also demonstrated to potentiate the cytotoxic and apoptotic abilities of anticancer drugs, including Vincristine, Vinblastine, and Dozorubicin ${ }^{23}$. Similarly, aqueous extracts and volatile oils from $M$. fructicosa displayed tumor prevention activity against human colon tumor cells, mammary carcinoma F7, and the human glioblastoma multiform cell line (U$87 \mathrm{MG})^{24,25}$.

In Lebanon, twelve Teucrium and eleven Micromeria species were reported to grow widely in the mount region $^{26}$. However, none of these plants were evaluated for its anticancer or other biological effect. In our previous work, the volatile oil of Micromeria fruticosa was analyzed and evaluated for its antimicrobial activity. Accordingly, this study aimed to evaluate the in vitro anticancer activities of $M$. fruticosa and T. polium, grown in Lebanon, against human breast cancer cell lines (MCF7) and human lung carcinoma cell lines (A549). In addition, we also aimed to determine their beneficial use as adjuvant to anticancer drugs.

\section{MATERIALS AND METHODS}

\section{Plant materials}

The aerial parts of Micromeria fruticosa and Teucrium polium were collected from a rocky mountain in the Lebanese Bekaa valley (1300m above sea level) during their full flowering period on July 2017.The plants were authenticated by Dr. Ali Chakas (Botanist from the Lebanese University, Faculty of Science). A voucher specimen of each plant was deposited in the herbarium of the Faculty of Pharmacy at the Beirut Arab University and give the specimen number Mf9-17 \&Tp-10-17 respectively.

\section{Preparation of plant extract}

The air-dried and ground aerial parts of M. fruticosa and T. polium were subjected to excessive alcoholic extraction at room temperature until exhaustion. 
The residues were removed by filtration. $M$. fruticosa extract (A) and that of T. polium (B) were concentrated using a rotary evaporator under reduced pressure at $35-40^{\circ} \mathrm{C}$ and then lyophilized into powders.

\section{Chemicals}

All organic solvents for column chromatography (CC) and thinlayer chromatography (TLC) (petroleum ether, ethyl acetate, and methanol) were analytical grade and purchased from Sigma-Aldrich ${ }^{\circ}$ (Germany). The alumina used was Neutral alumina 507 (for CC) and Silica-gel GF254 (for preparativeTLC) that were purchased from Fluka ${ }^{\circ}$ (Switzerland). TLC was performed on pre-coated silica gel 60 F254 purchased from ALUGRAM ${ }^{\circledR}$ SIL G (Germany). Methanol was used for recrystallization and LC-MS, while UV analysis was HPLC-grade purchased from Sigma-Aldrich ${ }^{\circledR}$ (Germany).

\section{Separation of crude extract}

Crude extracts of A and B were separated using column chromatography (silica gel, $350 \mathrm{~g}$, column diameter $3.5 \mathrm{~cm}$ ). Elution was carried out with gradient mixtures of petroleum ether (PE) and ethyl acetate (eluents from $20 \%$ to $100 \%$ EtOAc), and then continued with EtOAc and methanol (from $5 \%$ to $60 \%$ methanol) to give 22 fractions (A1-A22) for Micromeria fruticosa (extract A) and 43 fractions (B1-B43) for Toucrium polium (extract B). Each fraction was analyzed using TLC analysis, detected by UV lamp, and sprayed with different spray reagents to be visualized and to suggest the chemical class. Based on TLC analysis (Rf, shape, and spot color), similar fractions were combined together for further separation through CC to yield the sub fractions. The physical and chemical class of each fraction are shown in Table 1.

\section{Cell culture}

Human breast cancer cell lines (MCF7) and human lung carcinoma cell lines (A549) were purchased from the American Type Culture Collection (ATCC; Manassas, VA) and maintained in DMEM high glucose media (Sigma Chemical Company) supplemented with $0.1 \mathrm{mg} / \mathrm{ml}$ streptomycin, $100 \mathrm{U} / \mathrm{mL}$ penicillin, and $10 \%$ fetal bovine serum (FBS). Cell lines were maintained at $37^{\circ} \mathrm{C}$ under an atmosphere containing $5 \% \mathrm{CO}_{2}$.

Table 1: Physical and chemical properties of the separated fractions.

\begin{tabular}{|c|c|c|c|c|}
\hline Fraction & $\begin{array}{l}\text { Elution } \\
\text { solvent }\end{array}$ & TLC screening & $\begin{array}{l}\text { Number of } \\
\text { compounds }\end{array}$ & $\begin{array}{c}\text { Expected } \\
\text { chemical class }\end{array}$ \\
\hline A7 & $\begin{array}{c}(\mathrm{PE} / \\
\text { EtOAc80:20) }\end{array}$ & $\begin{array}{l}\text { Yellow with } \\
\text { conc } \mathrm{NH}_{3}\end{array}$ & $\begin{array}{l}1 \text { major } \\
2 \text { minor }\end{array}$ & Flavonoid \\
\hline A9 & $\begin{array}{c}(\mathrm{PE} / \\
\text { EtOAc70:30) }\end{array}$ & $\begin{array}{l}\text { Yellow with } \\
\text { conc } \mathrm{NH}_{3}\end{array}$ & $\begin{array}{l}1 \text { major } \\
1 \text { minor }\end{array}$ & Flavonoid \\
\hline A 10 & $\begin{array}{c}(\mathrm{PE} / \\
\text { EtOAc65:35) }\end{array}$ & $\begin{array}{l}\text { Yellow with } \\
\text { conc } \mathrm{NH}_{3}\end{array}$ & $\begin{array}{l}1 \text { major } \\
1 \text { minor }\end{array}$ & Flavonoid \\
\hline A11 & $\begin{array}{c}\mathrm{PE} / \\
\text { EtOAc70:30 }\end{array}$ & $\begin{array}{l}\text { Yellow with } \\
\text { conc } \mathrm{NH}_{3}\end{array}$ & $\begin{array}{l}1 \text { major } \\
1 \text { minor }\end{array}$ & Flavonoid \\
\hline A 15 & $\begin{array}{c}\text { PE/ } \\
\text { EtOAc50:50 }\end{array}$ & $\begin{array}{l}\text { Yellow with } \\
\text { conc } \mathrm{NH}_{3}\end{array}$ & $\begin{array}{l}2 \text { major } \\
1 \text { minor }\end{array}$ & Flavonoid \\
\hline B2 & $\begin{array}{c}\text { PE/ } \\
\text { ETAC70:30 }\end{array}$ & $\begin{array}{l}\text { Yellow with } \\
\text { conc } \mathrm{NH}_{3}\end{array}$ & $\begin{array}{l}1 \text { major } \\
2 \text { minor }\end{array}$ & Flavonoid \\
\hline B5 & PE/EtAc60:40 & $\begin{array}{l}\text { Yellow with } \\
\text { conc } \mathrm{NH}_{3}\end{array}$ & $\begin{array}{l}1 \text { major } \\
2 \text { minor }\end{array}$ & Flavonoid \\
\hline B10 & PE/EtAc30:70 & $\begin{array}{l}\text { Orange with } \\
\text { Dragendorff's }\end{array}$ & 1 major & Alkaloid \\
\hline B12 & PE/EtAc25:75) & $\begin{array}{l}\text { Yellow with } \\
\text { conc } \mathrm{NH}_{3}\end{array}$ & $\begin{array}{l}2 \text { major } \\
3 \text { minor }\end{array}$ & Flavonoid \\
\hline B13 & PE/EtAc20:80) & $\begin{array}{l}\text { Yellow with } \\
\text { conc } \mathrm{NH}_{3}\end{array}$ & $\begin{array}{l}1 \text { major } \\
2 \text { minor }\end{array}$ & Flavonoid \\
\hline B14 & (PE/EtAc15:85 & $\begin{array}{l}\text { Yellow with } \\
\text { conc } \mathrm{NH}_{3}\end{array}$ & $\begin{array}{l}1 \text { major } \\
1 \text { minor }\end{array}$ & Flavonoid \\
\hline
\end{tabular}

\section{Treatment of cells}

A $1 \mathrm{mg} / \mathrm{mL}$ stock solution of lyophilized plant extracts in DMSO was prepared, while the stock solution of the chemotherapeutic drug Cisplatin (CDDP) was diluted in $\mathrm{NaCl}$. Solutions were immediately sterilized by filtration through a sterile membrane filter with a porosity of 0.2 micron. Different concentrations were prepared by diluting the stock solution with DMSO. Cells were plated in 96-well micro titer plates, at a concentration of 105 cells/well, and incubated in a humidified environment of $37^{\circ} \mathrm{C}$ with a $5 \% \mathrm{CO} 2$ incubator for cell adhesion. The anti proliferative activity was carried out by measuring the cell viability of the MCF7 and A549 cell lines 72 hours after the treatment with increasing concentrations of total extracts $A$ and $B(10,20,30,40,50$, and $100 \mu \mathrm{g} / \mathrm{ml})$, their separated fractions $(100,150,200$, and $250 \mu \mathrm{g} /$ $\mathrm{ml})$, and cisplatin $(2,4,8,10,20$, and $40 \mu \mathrm{g} / \mathrm{ml})$. Similarly, MCF-7 and A549 cells were treated with combinations of total extracts A and B (20 $\mu \mathrm{g} / \mathrm{ml})$ and cisplatin $(2 \mu \mathrm{g} / \mathrm{ml})$. Untreated cells (the control) for plant extracts received DMSO, while cisplatin received $\mathrm{NaCl}$.

\section{Cell viability assay}

Cells were plated in 96-well plates at a density of 10,000 cells/well and treated with tested compounds and total extracts at different concentrations for 72 hours. A 3-(4, 5-dimethylthiazol-2-yl)-2,5diphenyltetrazolium bromide (MTT) solution $(5 \mathrm{mg} / \mathrm{ml})$ was added to evaluate mitochondrial viability ${ }^{27}$. After 4 hrs. of incubation at $37^{\circ} \mathrm{C}$, the supernatants were removed and $100 \mu \mathrm{l}$ of isopropanol-HCL was added to each well to solubilize the formazan crystals. The optical density, determined at $595 \mathrm{~nm}$, measured the signal and the background. The experiment was repeated three times independently, each time in triplicates. The percentage of viability for each sample was calculated using the obtained OD values within the following formula: Percentage of viability $(\%)=$ OD sample/OD control $\times 100$. The cytotoxicity of each compound is expressed as an IC50 value. The IC50 value is the concentration of test agents that caused a $50 \%$ inhibition or cell death averaged from at least three separate experiments. This value was obtained by plotting percentage inhibition versus concentration of compounds.

\section{Statistical analysis}

All results were presented as the mean \pm standard error of the mean (SEM). Statistical analyses were performed using GraphPadPrism 8 (GraphPad Software Inc., CA, USA). Two-way ANOVA was used to calculate sample probability values $(\mathrm{p}) ; \mathrm{p} \leq 0.05$ was considered statistically significant. Groups that are significantly different from the control are indicated in the Figures as ${ }^{*} \mathrm{p} \leq 0.05,{ }^{* *} \mathrm{p} \leq 0.01,{ }^{* *} \mathrm{p} \leq$ 0.001 , and $\mathrm{p} \leq 0.0001$.

\section{RESULTS}

Both the total extracts of Micromeria fruticosa (A) and Teucrium polium (B) and their separated fractions were found to reduce cell survival of MCF7 and A549 cancer cells.

The MTT assay was used to determine the proliferation rate of cancerous cell lines (MCF7 and A549) treated with different concentrations of total plant extracts A and B and their fractions. Results revealed that the cytotoxic activity of the total extract of the two plants were higher than their separated fractions. IC50 of extract A was $28.52 \pm 1.455$ and $26.47 \pm 1.423 \mu \mathrm{g} / \mathrm{ml}$ on MCF7 and A549 cell lines, respectively.While IC50 of extract B was $41.07 \pm 1.614$ and $27.97 \pm 1.447 \mu \mathrm{g} / \mathrm{ml}$ on MCF7 and A549 cell lines, respectively (Table 2 and Figure 1). Most of the separated fractions from A and B showed dose-dependent inhibitory activity on the cancerous cell lines. The most effective fraction isolated from extract A was 'A15' (IC50=186.67 \pm 2.271 on MCF7), and the most effective fraction separated from extract B 'was 'B5' (IC50=170.8 \pm 2.232 and $141.9 \pm 2.152$ on MCF7 and A549 cells, respectively) (Table 2). 
Table 2: IC50 values of total extracts $A$ and $B$ and their fractions $(\mu \mathrm{g} / \mathrm{ml})$.

\begin{tabular}{ccc}
\hline Compounds & MCF7 IC $_{50} \pm$ SEM $(\mu \mathrm{g} / \mathrm{ml})$ & A549 IC $_{50} \pm$ SEM $(\mu \mathrm{g} / \mathrm{ml})$ \\
\hline Total extract A & $28.52 \pm 1.455$ & $26.47 \pm 1.423$ \\
A7 & $>250$ & $>250$ \\
A9 & $>250$ & $>250$ \\
A10 & $>250$ & $>250$ \\
A11 & $>250$ & $>250$ \\
A15 & $186.7 \pm 2.271$ & $>250$ \\
& $41.07 \pm 1.614$ & \\
Total extract B & $>250$ & $>250$ \\
B2 & $170.8 \pm 2.232$ & $141.9 \pm 2.152$ \\
B5 & $223.7 \pm 2.350$ & $208.7 \pm 2.319$ \\
B10 & $>250$ & $>250$ \\
B12 & $>250$ & $>250$ \\
B13 & $>250$ & $>250$ \\
B14 & $14.74 \pm 1.168$ & $5.299 \pm 0,7242$ \\
Cisplatin & &
\end{tabular}
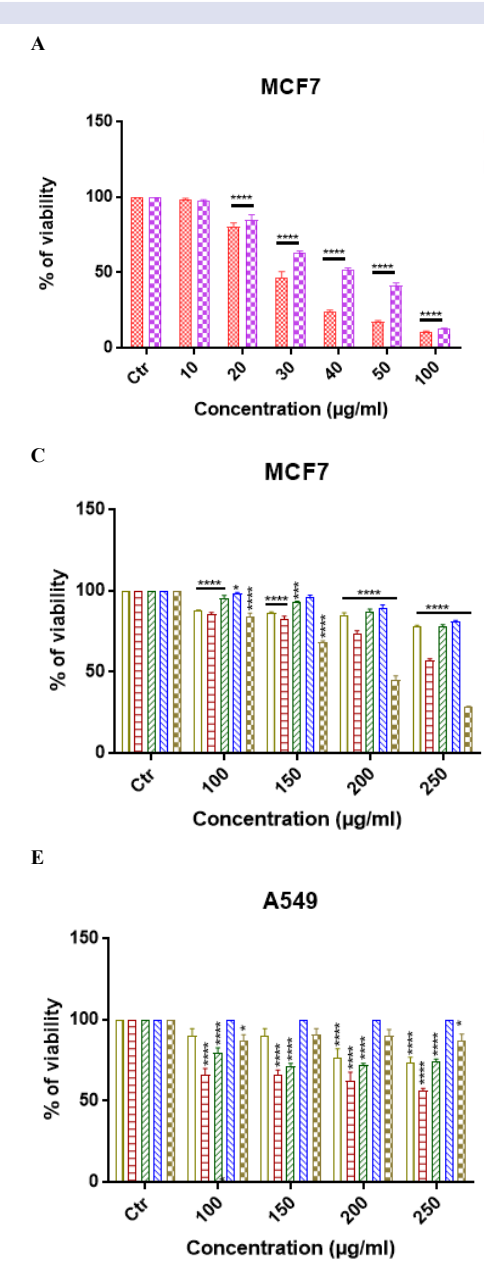
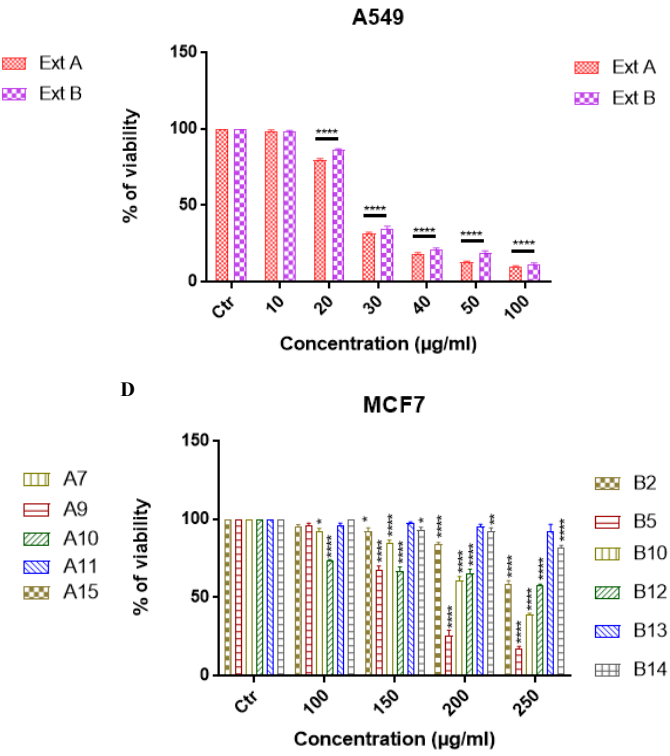

$\mathbf{F}$

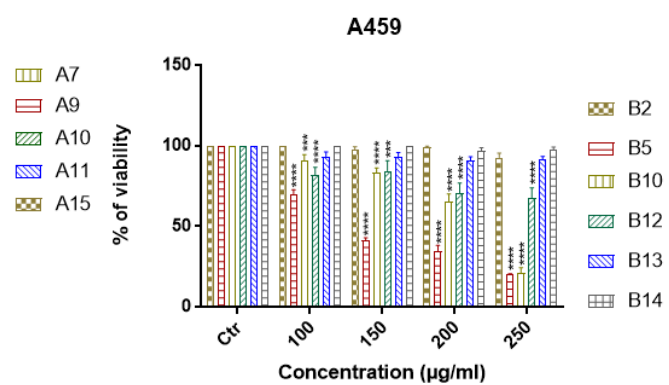

Figure 1: Total extract $A$ and $B$ and their separated fractions enhance the inhibition of proliferation in MCF7 and A549 cancer cell lines.A, F. MCF7 and A549 cells were incubated for 72 hrs with different concentrations $(0-250 \mu \mathrm{g} / \mathrm{ml})$ of total extract $A$ and $B$ and fractions. Cell viability was estimated by MTT test. Percent of the viability is calculated through the formula: \% viability $=$ OD (opticaldensity) of treated cells / OD of non-treated cells $\times 100$. Each column represents different concentrations of extracts. (A) Represents the total extract $A$ and $B$ in MCF7; $(B)$ represents the total extract $A$ and $B$ in A549; (C) represents the separated fractions of extract $A$ in MCF7; (D) represents the separated fractions of extract $B$ in MCF7; $(E)$ represents the separated fractions of extract $A$ in $A 549$; $(F)$ represents the separated fractions of extract $B$ in A549. Experiments were conducted in triplicates and results represent the mean \pm SEM (standard error of the mean) of $n=3$ independent experiments. The resultant P-value was expressed as ${ }^{*} \mathrm{P}<0.05$; ${ }^{* *} \mathrm{P}<0.01 ; \mathrm{P}^{* * *}<0.001$ was considered to be statistically highly significant and ${ }^{* * * *} \mathrm{P}<0.0001$ extremely significant (Two-way ANOVA).Ctr, control; Ext A,Micromeria fruticosa; Ext B,Teucrium polium. 


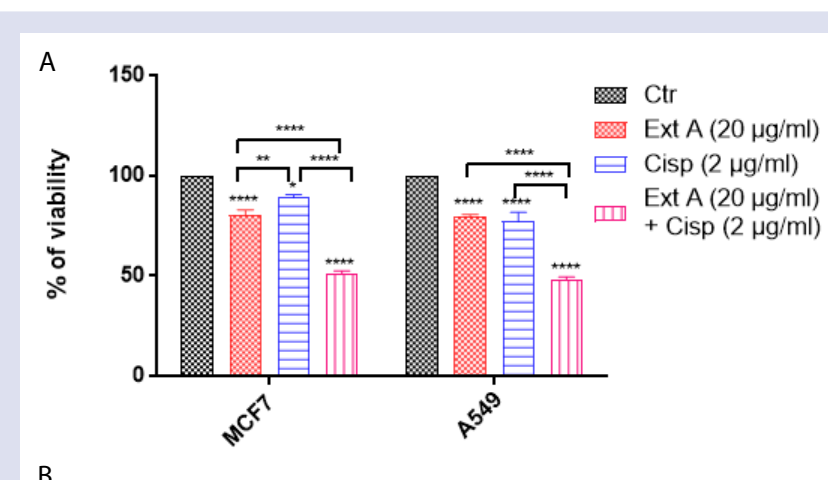

$B$
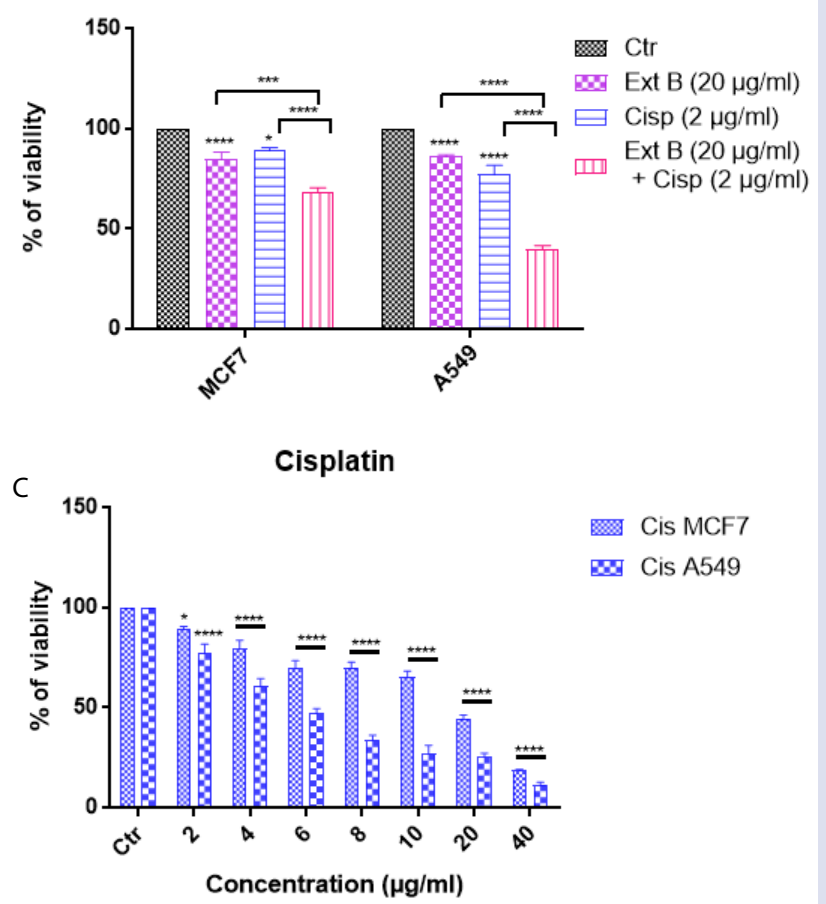

Figure 2: Effects of total extract $A$ and $B$ and/or cisplatin treatment on the cell viability of MCF7 and A549 cell lines.A, C.MCF7 and A549 cells were incubated for $72 \mathrm{hrs}$ with different concentrations $(0-40 \mu \mathrm{g} / \mathrm{ml})$ of cisplatin and with $20 \mu \mathrm{g} / \mathrm{ml}$ of total extract A and B.(A) Represents the total extract $A(20 \mu \mathrm{g} / \mathrm{ml})$ and/or cisplatin $(2 \mu \mathrm{g} / \mathrm{ml})$ in MCF7 and in A549 cell lines; (B) Represents the total extract B $(20 \mu \mathrm{g} / \mathrm{ml})$ and/ or cisplatin $(2 \mu \mathrm{g} / \mathrm{ml})$ in MCF7 and in A549 cell lines. (C) Represents the total extract $A(20 \mu \mathrm{g} / \mathrm{ml})$ and/or cisplatin $(2 \mu \mathrm{g} / \mathrm{ml}) \mathrm{B}$ in A549; (B) Represents the different concentrations $(0-40 \mu \mathrm{g} / \mathrm{ml})$ of cisplatin in MCF7 and in A549 cell lines. Experiments were conducted in triplicates and results represent the mean \pm SEM (standard error of the mean) of $n$ $=3$ independent experiments. The resultant $\mathrm{P}$-value was expressed as * $\mathrm{P}<0.05 ;{ }^{* *} \mathrm{P}<0.01 ; \mathrm{P}^{* * *}<0.001$ was considered to be statistically highly significant and ${ }^{* * *} \mathrm{P}<0.0001$ extremely significant (Two-way ANOVA). Cisp, cisplatin; Ext A,Micromeria fruticosa; Ext B, Teucriu Polium.

Co-treatment with cisplatin and plant extracts resulted in potentiation of the inhibitory effects on MCF7 and A549 cell viability. In the same method, the anti-proliferative activity of cisplatin on MCF7 and A549 cell lines was performed after 72 hours of treatment. The results showed that cisplatin inhibited the proliferation of MCF7 and A549 cancer cells in a concentration-dependent manner (Figure 2C). It was more effective against A549 cancer cells (IC50=5.299 $\pm 0,7242 \mu \mathrm{g} / \mathrm{ml}$ ) than MCF7 cancer cells (IC50=14.74 $\pm 1.168 \mu \mathrm{g} / \mathrm{ml}$ ). To investigate whether the combination of cisplatin and plant extracts may have a greater anticancer effect on the cell lines (A549 and MCF7) than single treatment, cells were treated with a low dose of cisplatin $2 \mu \mathrm{g} / \mathrm{ml}$ and low concentrations $(20 \mu \mathrm{g} / \mathrm{ml})$ of total plant extracts. The doses for cisplatin and plant extracts were based on results that revealed a low level of toxicity on cell lines. Results demonstrated that the combination treatment significantly enhanced the inhibitory effects on cell viability compared to total extract or cisplatin treatments alone in the MCF7 and A549 cell lines (Figure 3A and 3B). Taken together, these results showed that total extracts A and B boosted the cytotoxic effect of cisplatin against the two cancer cell lines.

\section{DISCUSSION}

Due to the damaging side effects of chemotherapy, alternative modalities to prevent and treat malignancies are highly demanded and desired. Screening of medicinal plants have been a promising approach to complement or possibly reduce the adverse side effects of chemotherapy ${ }^{22}$. This study showed that both Micromeria Fruticosa and Ticorium polium extract have dose-dependent inhibitory effect on the cancerous cell lines MCF7 and A549, with $\mathrm{IC}_{50}$ of $28.52 \pm 1.455$ and 26.47 $\pm 1.423 \mu \mathrm{g} / \mathrm{ml}$ for extract A, $41.07 \pm 1.614$ and $27.97 \pm 1.447 \mu \mathrm{g} / \mathrm{ml}$ for extract B on MCF7 and A549 cell lines, respectively. In addition, both plant extracts A and B significantly potentiated the inhibitory effect of cisplatin on cell viability compared with total extract or cisplatin alone on MCF7 and A549 cell lines. According to American National Cancer Institute, an IC50of $30 \mu \mathrm{g} / \mathrm{ml}$ or less has been identified as the criteria to determine significant cytotoxic activity of a plant extract ${ }^{28}$. Interestingly, our results identified lower values with $\mathrm{IC}_{50} 28.52 \pm$ 1.455 and $26.47 \pm 1.423 \mu \mathrm{g} / \mathrm{ml}$ for extract $\mathrm{A}, 41.07 \pm 1.614$ and $27.97 \pm$ $1.447 \mu \mathrm{g} / \mathrm{ml}$ for extract B on MCF7 and A549 cell lines respectively. The cytotoxic activity of $T$. polium were reported against melanoma (IC50 value $91.2 \mu \mathrm{g} / \mathrm{ml})^{29}$ and human breast adenocarcinoma MDA-MB-361 cells (IC50 value of $200 \mu \mathrm{g} / \mathrm{ml}$ ) ${ }^{22}$, but no data were found against MCF7 or A549 cell lines. Other studies reported that extract of $M$. fruticosa exerted ant proliferative activity with IC50 of 175 and $200 \mu \mathrm{g} / \mathrm{ml}$ against U-87 MG (glioblastoma multiform) cell lines ${ }^{25}$.

Accordingly, the inhibition effect of Lebanese plant species (Micormeria \&Tocorium) were much potent than other plants like Salvia (IC50=57$76 \mu \mathrm{g} / \mathrm{ml}$ ) against human melanoma cell lines (A375) and human foreskin fibroblast (HFF) cell lines ${ }^{30}$. The differences in IC50 between current results and previously reported studies may be attributed to the methods of extraction, different ecological factors, and cell type specificity. The augmentation of anti-proliferative activity of Cisplastin when co-administered with Micromeria or Teucrium extract suggested the plant as a potential adjuvant remedy in cancer therapy. Further studies are needed to explore the bioactive components in both plants responsible for this cytotoxic activity and possible mechanism of interactions.

\section{CONCLUSION}

This is the first study to report the anticancer activity of Micromeria fruticosa and Teucrium polium plants in Lebanon. Both plants showed high inhibitory activity against MCF7 and A549 cancer cell lines with IC50 below $30 \mu \mathrm{g} / \mathrm{ml}$. More interestingly, both plants significantly boosted the activity of cisplatin at low doses, suggesting the plants as new potential remedies in the cancer therapy.

\section{REFERENCES}

1. Reddy L, Odhav B, Bhoola K. Natural Products for Cancer Prevention: Global Perspective. Pharmacol. Ther. 2003;99:1-13.

2. Guo X, Zhu K, Zhang H, Yao H. Anti-Tumor Activity of A Novel Protein Obtained From Tartary Buckwheat. Int. J. Mol. Sci. 2010;11:5201-5211.

3. Cragg GM, Newman DJ. Plants as A Source Of Anticancer Agents. J. Ethopharmacol. 2005;100:72-79.

4. Tan G, Gyllenhaal C, Sorjarto DD. Biodiversity As A Source Of Anticancer Drugs. Curr. Drug Targets. 2006;7:265-277.

5. Takhtajan A. Diversity and Classification of Flowering Plants. Newyork, Columbia NiversityPress 1997; 465-9. 
6. M. Al-Hamwi, Y. Bakkour, M. Abou-Ela, A. El-Lakany, M. TabchehAnd F. El-Omar. Chemical, J. Nat. Prod., 4, 147 (2011).

7. Tutin, T.G.; Wood, D. Teucrium. In Flora Europaea, 1st Ed.; Tutin, T.G., Heywood, V.H., Burges, N.A., Moore, D., Valentine, D., Walters, S., Eds.; Cambridge University Press: Cambridge, UK, 1972; Volume 3, Pp. 129-135.

8. Šilić Č. MonografijaRodovaSatureja L., Calamintha Miller, MicromeriaBentham, Acinos Miller I Clinopodium L. U FloriJugoslavije. Sarajevo: ZemaljskiMuzejBih; 1979. 440 P. Serbo-Croatian.

9. Kästner, A. ÜbersichtZurSystematischenGliederung Der GattungTeucrium L. BiocosmeMésogéen 1989, 6, 63-78.

10. Bisset NG, Wichtl M, Eds. Herbal Drugs and Phytopharmaceuticals. Boca Raton, London, New York, Washington D.C., Crcpress 2001.

11. Nativ D, Olga L, Uzi R, Eliputie V, Efraim L. Developmental Control Of Monoterpene Content And Composition In MicromeriaFruticosa (L.) Druce. Ann Bot 2001;88:349-54.

12. Mehmet E, Mehmet O, Aysel U, Ozgur C. The Constituents of Essential Oil and In Vitro Antimicrobial Activity of Micromeria Cilicica From Turkey. Ethnopharmacology2004; 94:43-8.

13. Ali-Shtayeh M, A1-Nuri M, Reem M, Yaghmour A, FaidiY. Antimicrobial Activity Of MicromeriaNervosa FromThe PalestinianArea. J Ethnopharmacol1997;58:143-7.

14. Abu-Gharbieh E, Shehab NG, Khan SA. Antiinflammatory And Gastroprotective Activities of The Aqueous Extract Of Micromeriafruticosa (L.) DruceSspSerpyllifolialn Mice. Pak J Pharm Sci2013; 26: 799- 803.

15. Abu-Gharbieh E, Bustanji Y, Mohammad M. In Vitro Effects Of Micromeria fruticose On Human Leukocyte Myeloperoxidase Activity. JPR Solutions 2010; 3: 2492-2493.

16. Eman Abu-GharbiehAnd Naglaa G Ahmed. Bioactive Content, Hepatoprotective And Antioxidant Activities of Whole Plant Extract Of Micromeria Fruticosa (L) DruceSsp Serpyllifolia F Lamiaceae Against Carbon Tetrachloride-Induced Hepatotoxicity In Mice, Tropical Journal Of Pharmaceutical Research October 2016; 15 (10): 2099-2106.

17. Milan S. Stankovic, Milena G. Curcic1, Jovana B. Zizic, Marina D. Topuzovic, Slavica R. Solujic And Snezana D. MarkovicTeucrium Plant Species As Natural Sources Of Novel Anticancer Compounds: Antiproliferative, Proapoptotic And Antioxidant Properties, Int. J. Mol. Sci. 2011, 12, 4190-4205.

18. Milan S. STANKOVIC,TatjanaLj. MITROVIC, Ivana Z. MATIC, Marina D. TOPUZOVIC, Slaviša M. STAMENKOVIC. New Values OfTeucrium Species: In Vitro Study Of Cytotoxic Activities Of Secondary Metabolites, Not Bot HortiAgrobo, 2015, 43(1):41-46. DOI:10.15835/Nbha4319746.
19. FatihaBrahmi, Naima Guendouze, Didier Hauchard, PhillipeOkusa, LéocadieKamagaju, KhodirMadani\& Pierre DuezMicromeriaGraeca (L.) Benth Ex Rchb. Phenolic Profile and Biological Activities of MicromeriaGraeca (L.) Benth. Ex Rchb. International Journal of Food Properties 2017, Vol. 20, No. S2, S2070-S2083

20. Kandouz $M$, Alachkar A Zhang $L$ Dekhil $H$ Chehna $F$ Yasmeen A TeucriumPolium Plant Extract Inhibits Cell Invasion And Motility Of Human Prostate Cancer Cells ViaThe Restoration Of The E-Cadherin/Catenin Complex. J Ethnopharmacol2010;129:410-5.

21. Haïdara K, Alachkar A, Al Moustafa A. Teucrium Polium Plant Extract Provokes Significant Cell Death in Human Lung Cancer Cells. Health 2011;3:366-9.

22. Sabry A. El-Naggar, Mousa O. Germoush, Ibrahim B. Abdel-Farid, Hassan A Elgebaly, Abdelhalim A. Alkazendar. Phytochemical Analysis And Anticancer Screening Of Some Indigenous Plants Grown In Saudi Arabia, Journal Of Cancer And Biomedical Research (JCBR) Vol. 1 (1): 19-27.

23. Rajabalian S. Methanolic Extract Of Teucrium Polium L. Potentiates the Cytotoxic and Apoptotic Effects of Anticancer Drugs Of Vincristine, Vinblastine And Doxorubicin Against A Panel Of Cancerous Cell Lines. Exp. Oncol. 2008; 30:133-138.

24. Shehab NG, Abu-Gharbieh E. Constituents and Biological Activity of Essential Oil and Aqueous Extract of Micromeria Fruticosa L DruceM. Serpyllifolia. Pak J Pharm Sci2012;

25. Kubra Koc, OzlemOzdemir, Omer FarukKizilkaya, Meryem Sengul And Hasan Turkez. Cytotoxic Activity of the Aqueous Extract Of Micromeria fruticosa (L.) DruceSubsp. Serpyllifolia On Human U-87 MG Cell Lines, Archives Of Biological Sciences · January 2016 DOI: 10.2298/ABS160504119K.

26. Georges Tohme, Henriette, Illustrated Flora Of Lebanon,CNRS Publication,2007

27. Varache-Lembège, M., Moreau, S., Larrouture, S., Montaudon, D., Robert, J., AndNuhrich, A. 2008. Synthesis AndAntiproliferative Activity of Aryl- And Heteroaryl-Hydrazones Derived From Xanthonecarbaldehydes. European Journal of Medicinal Chemistry, 43(6), 1336-1343.

28. Suffness, M., Pezzuto, J.M. (1990): Assays Related To Cancer Drug Discovery. In:Hostettman, K. (Ed.). Methods in Plant Biochemistry: Assay for Bioactivity. AcademicPress, London, Pp. 71-133.

29. Federica Menichini, FilomenaConforti, Daniela Rigano, Carmen Formisano,Franco Piozzi, FeliceSenatore. Phytochemical Composition, AntiInflammatory and Antitumour Activities of Four Teucrium Essential Oils from Greece, Food Chemistry 115 (2009) 679-686.

30. Antonios Koutsoulas, Martina Čarnecká, JiříSlanina,JaroslavTóth And Iva Slaninová. Characterization of Phenolic Compounds and Antiproliferative Effects of Salvia Pomifera and Salvia Fruticosa Extracts, Molecules. 2019 Aug; 24(16): 2921. 


\section{GRAPHICAL ABSTRACT}
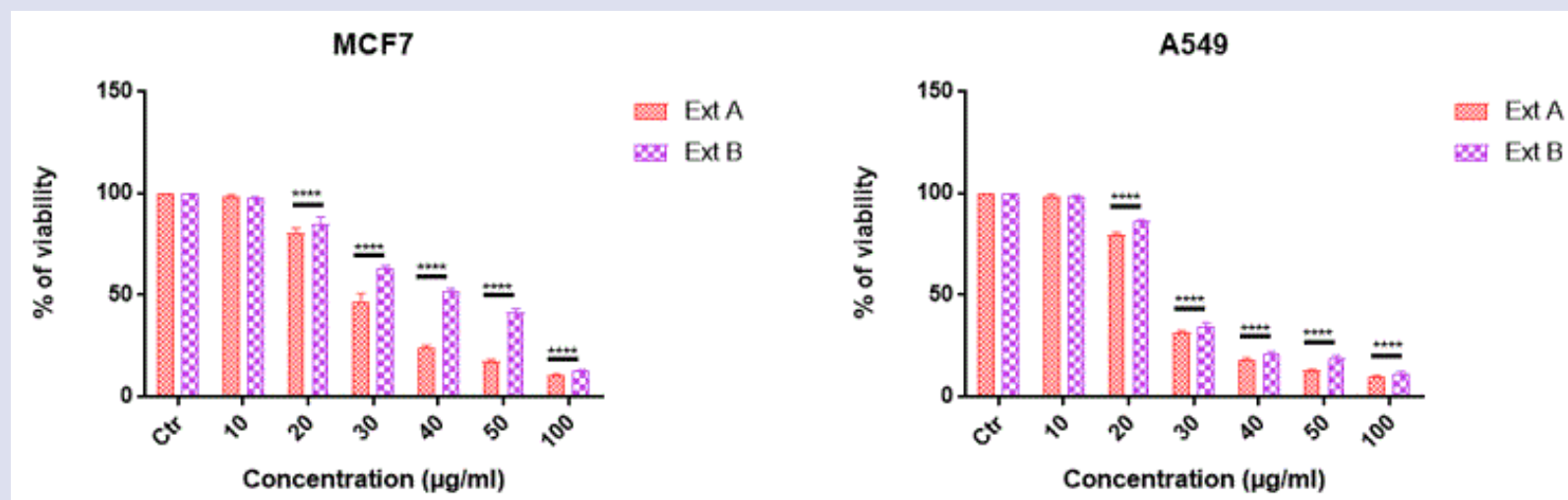

ExtA
Ext B

Box ExtB

Concentration $(\mu \mathrm{g} / \mathrm{ml})$
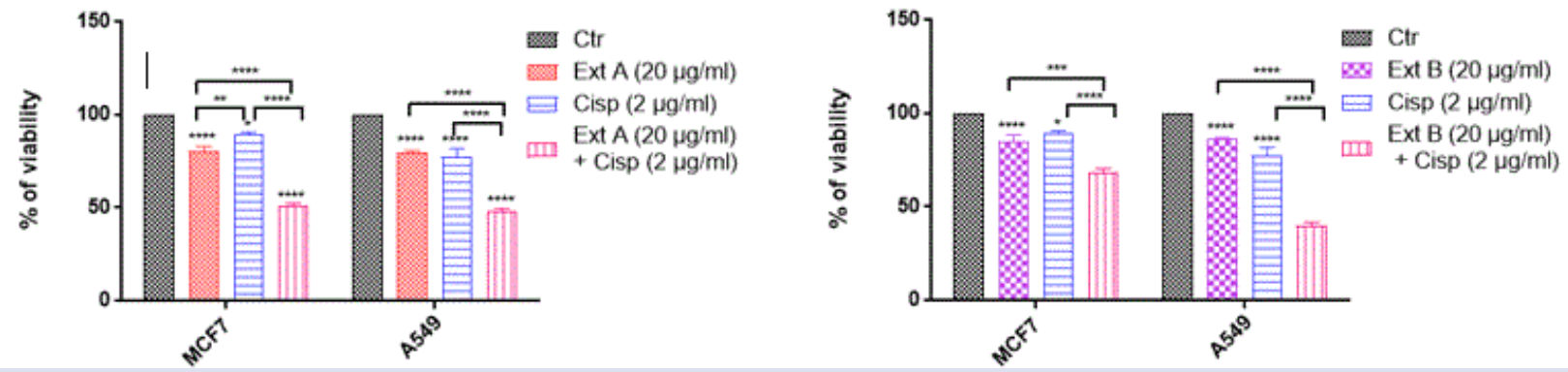

\section{ABOUT AUTHORS}

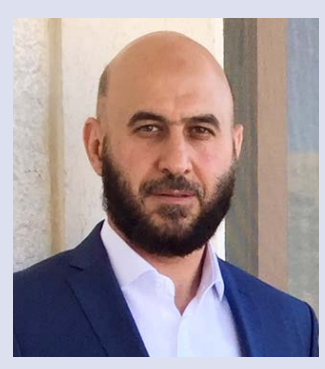

Mohamad Al- Hamwi, is a graduate of the Faculty of Pharmacy, Beirut Arab University, Master degree in Pharmacognosy and Medicinal plants, pharmaceutical sciences department, faculty of Pharmacy, BAU. Ph.D. candidate in pharmaceutical sciences department faculty of Pharmacy, BAU.

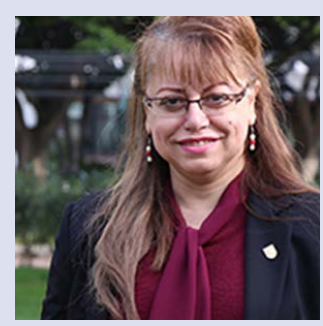

Prof Maha Aboul Ela. is a graduate of the Faculty of Pharmacy, University of Alexandria, Egypt. She has done her Ph.D. at the Department of Pharmacognosy, Faculty of Pharmacy, the University of Alexandria in collaboration with the Institute for Organic Chemistry, Technical University of Berlin, Germany. She has more than fifty publications in national and international journals and is the head of the pharmaceutical sciences department faculty of Pharmacy, Beirut Arab University.

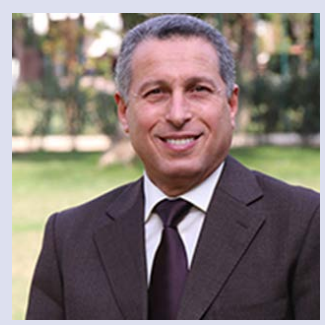

Prof Abdalla El-Lakany, is a graduate of the Faculty of Pharmacy, Alexandria University. Based on academic excellence, he was granted a Ph.D. scholarship from the Faculty of Pharmacy, Alexandria University. He has published several research articles in the medicinal plant domain. Currently, he is the dean of the Faculty of Pharmacy at Beirut Arab University. 


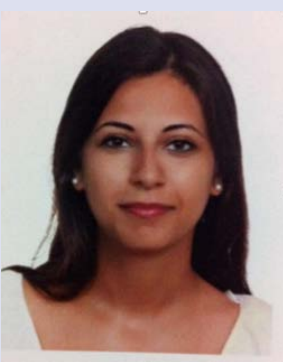

Salam Naser Eddine, Ph.D. in Immunology and Biotherapy from University of Paris-Sud 11, France, Professor in Biology at Lebanese University- Faculty of Sciences, a researcher in collaboration with Faculty of Medicine, American University of Beirut.

Cite this article: Al-Hamwi M, Aboul-Ela M, El-Lakany A, Nasreddine S. Anticancer Activity of Micromeria fruticosa and Teucrium polium Growing in Lebanon. Pharmacog J. 2021;13(1): 103-9. 